\title{
Impact of Family Income on Public's Disaster Preparedness and Adoption of DRR Courses
}

\author{
Thahomina Jahan Nipa ${ }^{1}$, Sharareh Kermanshachi ${ }^{2}$ and Ronik Ketankumar Patel ${ }^{3}$
}

1 University of Texas at Arlington, Arlington, USA, thahomina.nipa@mavs.uta.edu

2 University of Texas at Arlington, Arlington, USA, sharareh.kermanshachi@uta.edu

3 University of Texas at Arlington, Arlington, USA, ronikketankumar.patel@mavs.uta.edu

\begin{abstract}
When disasters occur, they affect a community's educational institutions, yet students are still one of the most ignored groups of people when it comes to disaster preparedness. Demographic characteristics highly determine and influence the effects of a disaster; hence, when preparing for it, the students' demographic information should be considered. Little research exists in the literature that addresses the impacts of such characteristics on students' preparedness. Therefore, this study aims to identify the impacts of demographic information related to family income on students' perceptions of disaster preparedness and disaster risk reduction (DRR) education. To fulfill this goal, a survey was conducted, and 111 responses were collected. Statistical analysis revealed a several intriguing conclusions. It was found that all of the students, irrespective of their family income, realize the necessity of DRR education and are willing to take the course if it is offered. Family income comes into play, however, when the resources of the DRR courses are discussed. Students with different family incomes have different perceptions regarding phycological first aid training and knowledge of disaster medicine included in DRR courses. It was found that family income has a significant impact on students' awareness regarding emergency procedures and communication systems offered by the university, as well as on students' confidence in assisting the university with disaster management during a disaster. This study will help educational institutions and practitioners develop DRR resources that will be best suited for the students with certain demographic characteristics.
\end{abstract}

(c) 2020 The Authors. Published by Budapest University of Technology and Economics \& Diamond Congress Ltd Peer-review under responsibility of the Scientific Committee of the Creative Construction Conference 2020.

Keywords: disaster preparedness, family income, students' perception of DRR education

\section{Introduction}

Factors like global warming, population density, and climate change are contributing to a continuous increase in the intensity and frequency of natural disasters $[1,2,3]$. With their unexpectedness and unthinkable destructive powers, they cause physical as well as psychological damages to the public and the environment [4, 5, 6, 7, 8, 9]. From 2016 to 2017, the monetary value of damages due to natural disasters was approximately $\$ 200$ billion worldwide $[10,11,12,13]$, and in 2018,355 people died as a result of a natural disaster in the United States [14]. To reduce these damages, all three phases of a disaster timeline must be prepared for: pre-disaster phase, disaster-impact phase, and post-disaster phase $[15,16,17,18]$. The pre-disaster phase mainly focuses on the preparedness of the community and people [19]. When people are not prepared to face a disaster, its impact increases several folds [20,21]. When victims are unable to establish contact with their close family while they are suffering from the disaster, it increases their mental distress [22, 23, 24]. In 2003, after understanding the importance of preparedness, the Federal Emergency Management Agency (FEMA) established a campaign called "Ready," which they update periodically $[22,25]$. During the last update in 2019, they provided preparedness resources for kids, teens, families, educators, and organizations. Like this program, however, current research on disaster 
preparedness did not recognize the importance of preparedness for students, even though they are one of the most vulnerable groups when a disaster-affected area contains an educational institution.

Students are more vulnerable to disasters than the general population [26], as they lack basic preparedness knowledge [27]. In addition to suffering from physical injuries, they also endure emotional and behavioural disorders from which it takes a long time to recover. It is, therefore, important to establish the Disaster Risk Reduction (DRR) curriculum in educational institutions [28]. The students' demographics and the factors that affect their preparedness are important to such a curriculum, but the effects of some of the demographic factors are still unclear $[29,30]$.

This study aims to investigate the effects of the demographic factor, family income, on the students' disaster preparedness by fulfilling the following objectives: (i) performing a thorough literature review on disaster preparedness and students' perception of it, (ii) identifying the variables that determine the effects of family income on students' perception of disaster preparedness, and (iii) identifying the effects of family income on students' perception of DRR education and disaster preparedness. The findings of this study will help academic staff and practitioners take the steps necessary to better prepare the students for a disaster.

\section{Literature review}

\subsection{Effects of disaster on students and educational institutions}

Education quality of a society has a great impact on its economic level [31]; hence careful care should be devoted to ensuring that educational institutions are fully functional at their best quality level [32, 33]. Disasters can affect students in many ways. Jaradat et al. [34] claimed that disasters can affect universities by destroying the buildings and injuring the students, faculty, and staff, in addition to destroying the research data, laboratory samples, library resources, etc. Sometimes, disasters have long-term effects on educational institutions by damaging their water supplies and electricity [34]. Yet, students are not given their due compared to other groups of affected people. Mulilis et al. [35] found that students' level of preparedness is very low, as they don't have the proper knowledge and skills, partially due to their lack of interest [36], but also because teachers are not motivated to effectively teach disaster risk reduction courses [37]. Even though it is important to have a certain level of awareness regarding disasters [38], the awareness is not equivalent to being prepared. Being prepared also requires being able to successfully implement rescue practices during a disaster [39, 40].

\subsection{Effect of demographic factors in disaster preparedness}

Disaster preparedness can substantially reduce the negative impacts of disasters, and demographic factors often modify the preparedness of an individual [30]. Many researchers have studied the relationship between demographic factors and disaster preparedness. For example, Kim and Zakour [41] found that people from a community in which there is a strong bond among the residents tend to be better prepared for a disaster. Donner and Lavariega-Montforti [42] found that gender, education, and ethnicity do not necessarily have a direct connection with preparedness, but previous experience and income do. Yao [43] conducted a study of 349 participants to determine the influence of demographic factors on disaster preparedness and found that age and education level have little connection with the level of preparedness of the individual. Kaser et al [44] found that the demographic characteristics of an individual determine his/her preparedness for effective communication during a disaster.

\subsection{Effect of income on disaster preparedness}

Research shows that disaster preparedness is dependent on personal and family income. Kim and Zakour [41] established a direct relationship between income and available resources required for disaster preparedness. Doner and Lavariega-Montforti [42] found that those with higher income levels tend to store emergency supplies and/or build a shelter, which increases their level of emergency preparedness. However, their research, based on a community, did not conclude whether family income plays a role in the preparedness of the students. Gilhooly [45] found that people from low-income families often struggle with emergency preparedness. Above discussion emphasize the need to look into the relationship between family income and students' disaster preparedness. 


\subsection{Disaster preparedness and students}

Donner and Lavariega-Montforti [42] found that older adults are more prepared than younger people to face a disaster. Young people attending schools and universities are the most vulnerable, as they are there for a significant portion of the day, without a legal guardian's supervision. Tan et al. [36] found that more than $70 \%$ of students desire DRR courses and would be willing to take them, as they lack confidence in their ability to survive a disaster. Unfortunately, government agencies mainly focus on disaster preparedness and rehabilitation at the community level and pay very little attention to students' preparedness [37].

The literature review signifies that even though there is a fair amount of research on the influence of demographic factors on disaster preparedness and students' preparedness, there is a dearth of information on how the demographic characteristics affect students' disaster preparedness. Studies that focus on the influence of family income on disaster preparedness of the students' are even rarer. Hence, the goal of this study is to investigate the impacts of family income on students' disaster preparedness.

\section{Research methodology}

This research followed the five-step methodology shown in Figure 1. The first step focused on conducting a thorough literature review to help the authors understand the current condition of the literature regarding students' disaster preparedness and to identify a list of variables for use in performing a statistical analysis. In the second step, questions for each variable, along with demographic questions, were developed for the survey. After that, the survey was pilot tested and modified based on the responses to make it more appropriate for the participants. After collecting the survey responses, descriptive and quantitative analyses were conducted.

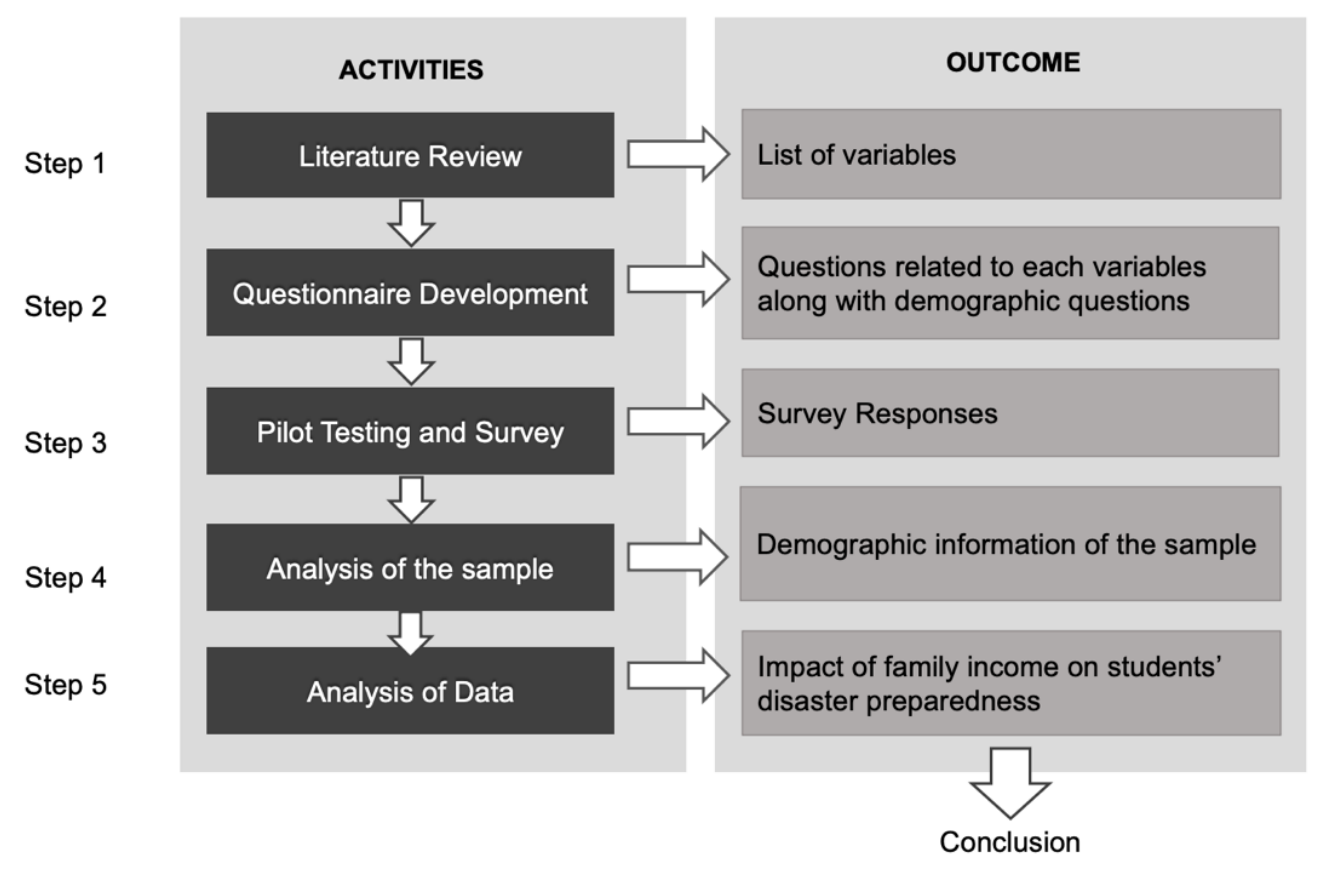

Fig. 1. Research methodology

As most of the questions in the survey followed a seven-point Likert scale, this study used the Kruskal-Wallis test to determine the differences in the way that students perceived the variables of disaster preparedness. SPSS software was used to perform the tests, and for greater precision, both $90 \%$ and $95 \%$ levels of confidence were considered. Table 1 shows the hypotheses developed for this study. 
Table 1. Adopted hypotheses for the study.

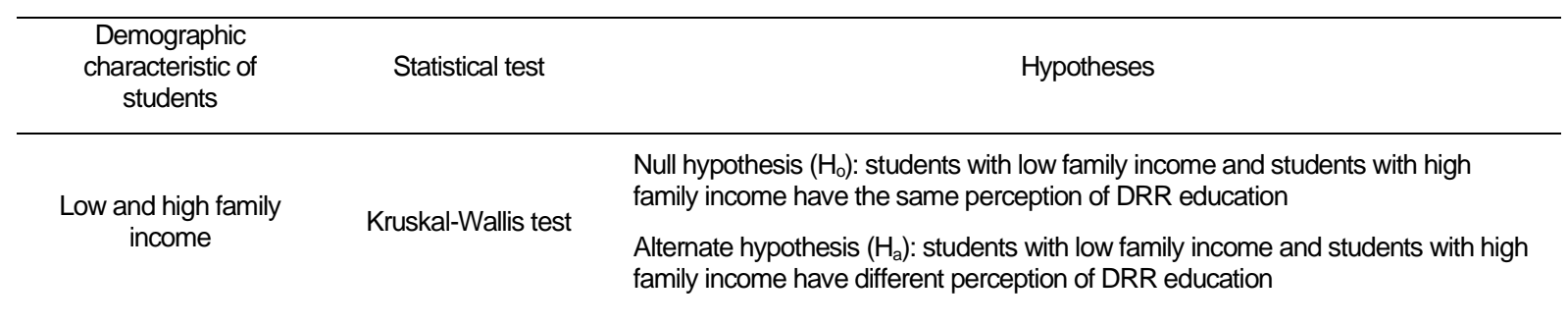

\section{List of variables}

Based on the literature review, a list was made of the variables that identify the level of preparedness of students (Table 2). The variables were arranged into five categories.

Table 2. P-Values testing the significance of students' perception of disaster preparedness and Disaster Risk Reduction (DRR) education.

\begin{tabular}{|c|c|c|}
\hline Category & \# & Variables \\
\hline \multirow{5}{*}{ DRR education } & 1 & DRR education should be made mandatory \\
\hline & 2 & Willingness to take DRR course \\
\hline & 3 & Likelihood of giving a test based on DRR education \\
\hline & 4 & Curriculum provides psychological first aid training \\
\hline & 5 & Curriculum or disaster drill include knowledge regarding disaster medicine \\
\hline \multirow{4}{*}{ University resources } & 6 & University has online database regarding disaster preparedness \\
\hline & 7 & University has enough first aid boxes \\
\hline & 8 & University buildings have disaster shelter \\
\hline & 9 & University include student's guardian while providing disaster education \\
\hline \multirow{2}{*}{ Community help } & 10 & Importance of local communities on helping university to implement DRR courses \\
\hline & 11 & Importance of local communities to help university \\
\hline \multirow{6}{*}{ Awareness and experience } & 12 & Open to collaborate while handling a disaster \\
\hline & 13 & Confidence to assist with disaster management during emergency \\
\hline & 14 & Confidence in providing basic first aid \\
\hline & 15 & Impact of severe natural disaster on student's life \\
\hline & 16 & Awareness of the emergency procedures in the university \\
\hline & 17 & Awareness of communication system provided by university during emergency \\
\hline \multirow{5}{*}{ Safety responsibility } & 18 & Students are responsible for their own safety \\
\hline & 19 & Friends are responsible for students' safety \\
\hline & 20 & Parents are responsible for students' safety \\
\hline & 21 & University is responsible for students' safety \\
\hline & 22 & Government Agencies are responsible for students' safety \\
\hline
\end{tabular}

The first category is related to DRR education and includes the variables that indicate the requirement of DRR education and the students' perspectives towards the DRR curriculum. The second category is the university resources, which examines students' knowledge about the university's disaster-related supplies. The third category is the community assistance, which includes the variables that help understand students' perspectives regarding the community's role in the university's disaster preparedness. The fourth category is awareness and experience, which examines students' perspectives of their personal disaster awareness and experience. The fifth category is safety responsibility, which focuses on the students' beliefs about who is responsible for their safety during a disaster. 


\section{Survey development}

Questions for each variable were prepared, using a seven-point Likert scale option. Demographic questions consisted of gender, year of birth, ethnicity, family income, etc. Figure 2 shows a couple sample questions of the survey.

Choose best suited option based on you understanding

\begin{tabular}{|c|c|c|c|c|c|c|c|}
\hline $\begin{array}{l}\text { How important it is for the local } \\
\text { entities to help universities to } \\
\text { implement DRR courses? }\end{array}$ & $\begin{array}{l}\text { Not at all } \\
\text { Important } \\
\text { O }\end{array}$ & $\begin{array}{c}\text { Slightly } \\
\text { Important } \\
\mathrm{O}\end{array}$ & $\begin{array}{c}\text { Somewhat } \\
\text { Important } \\
\end{array}$ & $\begin{array}{c}\text { Moderately } \\
\text { Important } \\
\text { O }\end{array}$ & $\begin{array}{c}\text { Very } \\
\text { Important } \\
\mathrm{O}\end{array}$ & $\begin{array}{c}\text { Quite } \\
\text { Important } \\
\mathrm{O}\end{array}$ & $\begin{array}{c}\text { Extremely } \\
\text { Important } \\
\mathrm{O}\end{array}$ \\
\hline $\begin{array}{l}\text { Do you agree that university } \\
\text { should include guardian while } \\
\text { providing disaster } \\
\text { preparedness education? }\end{array}$ & $\begin{array}{l}\text { Strongly } \\
\text { disagree }\end{array}$ & Disagree & $\begin{array}{c}\text { Somewhat } \\
\text { Disagree } \\
0\end{array}$ & Neutral & $\begin{array}{l}\text { Somewhat } \\
\text { Agree }\end{array}$ & Agree & $\begin{array}{l}\text { Strongly } \\
\text { Agree }\end{array}$ \\
\hline
\end{tabular}

Fig. 2. Sample of the survey

The survey was pilot-tested and modified accordingly to make it appropriate for the intended participants.

\section{Demographic information of the sample}

The survey responses were analyzed and organized to portray the demographic information of the participants (Table 3). The majority of the participants were young Asians, under 25 years old. Only $11 \%$ of the participants were older than 29 . The annual family income of $16 \%$ of the participants was less than $\$ 15,000$, and $9 \%$ of the total participants had an annual family income greater than $\$ 100,000$.

Table 3. Demographic information of the survey.

\begin{tabular}{llcc}
\hline \multicolumn{1}{c}{ Category } & \multicolumn{1}{c}{ Division } & Number in sample & Percentage in sample \\
\hline \multirow{3}{*}{ Ethnicity } & Native American & 0 & $0 \%$ \\
& African American & 7 & $7 \%$ \\
& Asian & 68 & $65 \%$ \\
& Hispanic & 12 & $11 \%$ \\
& Other & 18 & $17 \%$ \\
\hline \multirow{3}{*}{ Age range } & Under 25 years old & 68 & $61 \%$ \\
& Between 25 to 29 years & 43 & $39 \%$ \\
& Above 29 years old & 11 & $10 \%$ \\
\hline \multirow{3}{*}{ Annual family income } & Less than $\$ 15,000$ & 16 & $16 \%$ \\
& $\$ 15,000$ to $\$ 30,000$ & 28 & $28 \%$ \\
& $\$ 30,000$ to $\$ 60,000$ & 18 & $18 \%$ \\
& More than $\$ 100,000$ & 28 & $28 \%$ \\
\end{tabular}

\section{Analysis of the students' perception of disaster preparedness and DRR education based on family income}

Table 4 shows the results of the Kruskal-Wallis test for students with a low family income and a high family income. These values are important to understanding students' perceptions of their preparation to handle a disaster and whether the perceptions were influenced by their family income. 
Table 4. Kruskal-Wallis test result for the students with low and high family income

\begin{tabular}{|c|c|c|c|}
\hline Category & \# & Variables & $\begin{array}{c}\text { P-Values for } \\
\text { Students with Low } \\
\text { and High Family } \\
\text { Income }\end{array}$ \\
\hline \multirow{5}{*}{ 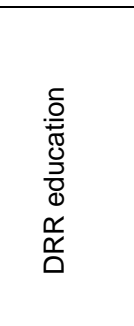 } & 1 & DRR education should be made mandatory & 0.308 \\
\hline & 2 & Willingness to take DRR course & 0.688 \\
\hline & 3 & Likelihood of giving a test based on DRR education & 0.717 \\
\hline & 4 & Curriculum provides psychological first aid training & $0.079^{*}$ \\
\hline & 5 & Curriculum or disaster drill include knowledge regarding disaster medicine & $0.102^{*}$ \\
\hline \multirow{4}{*}{ 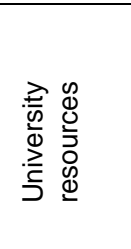 } & 6 & University has online database regarding disaster preparedness & 0.213 \\
\hline & 7 & University has enough first aid boxes & $0.033^{* \star}$ \\
\hline & 8 & University buildings have disaster shelter & 0.136 \\
\hline & 9 & University include student's guardian while providing disaster education & 0.427 \\
\hline \multirow{2}{*}{ 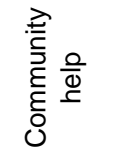 } & 10 & Importance of local communities on helping university to implement DRR courses & 0.640 \\
\hline & 11 & Importance of local communities to help university & 0.153 \\
\hline \multirow{6}{*}{ 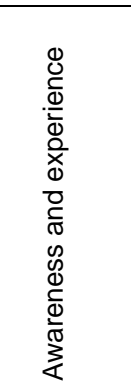 } & 12 & Open to collaborate while handling a disaster & 0.120 \\
\hline & 13 & Confidence to assist with disaster management during emergency & $0.030^{* *}$ \\
\hline & 14 & Confidence in providing basic first aid & 0.837 \\
\hline & 15 & Impact of severe natural disaster on student's life & 0.188 \\
\hline & 16 & Awareness of the emergency procedures in the university & $0.051^{*}$ \\
\hline & 17 & Awareness of communication system provided by university during emergency & $0.086^{*}$ \\
\hline \multirow{5}{*}{ 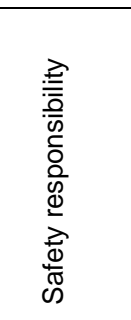 } & 18 & Students are responsible for their own safety & 0.624 \\
\hline & 19 & Friends are responsible for students' safety & 0.133 \\
\hline & 20 & Parents are responsible for students' safety & 0.617 \\
\hline & 21 & University is responsible for students' safety & 0.444 \\
\hline & 22 & Government Agencies are responsible for students' safety & 0.146 \\
\hline
\end{tabular}

\section{Interpretation of the result based on Kruskal-Wallis test}

\subsection{DRR education}

The majority of the students, irrespective of their family income, believe that DRR education should be mandatory and are willing to take the course when it is offered by their institution. They are also willing to take a test that will assess their understanding of DRR. This shows that even though they are young, they are concerned about their preparedness to face a disaster. Not all of the students are satisfied with the design of the curriculum of the DRR education, however. Students from low- and high-income families have different perceptions of the psychological training and knowledge of medicine that the curriculum offers.

\subsection{University resources}

The majority of students, regardless of their family income, have the same perception of most of the disaster preparedness resources that the university offers. They believe that a university should have an 
online disaster database and a disaster shelter, and that the university should include their guardians in their efforts to better prepare the students for a disaster. However, students from low-income families and students from high-income families have different perspectives regarding the number of available first aid boxes.

\subsection{Community help}

Irrespective of the differences in the demographic characteristics of the students, all of them believe that it is impossible for them to have a satisfactory level of disaster preparedness without the community collaborating with the university. They also believe that the community can play a vital role in helping the institution implement DRR courses.

\subsection{Awareness and experience}

Family income doesn't necessarily impact the students' willingness to collaborate while handling a disastrous situation and providing basic first aid. Irrespective of their demographic characteristic, they believe that a disaster's impact on them can be severe; however, family income affects confidence and awareness levels. For example, students from low- and high-income families have different levels of awareness regarding the university's emergency procedures and communication system for handling a disaster.

\subsection{Safety responsibility}

From Table 4 it is evident that family income does not necessarily impact the students' perceptions regarding who is responsible for the safety of the students, themselves, friends, parents, university, and government agencies, during a disaster.

\section{Interpretation of the result: based on box plots}

To understand the effects that family income has on students' perceptions regarding disaster preparedness, a box plot for the variable "confidence to assist with disaster management during an emergency," with p-value 0.030 (Table 4) was drawn (Figure 3). It is evident from the figure that the students from the high-income families are more confident in rendering assistance during emergencies than those from low-income families.

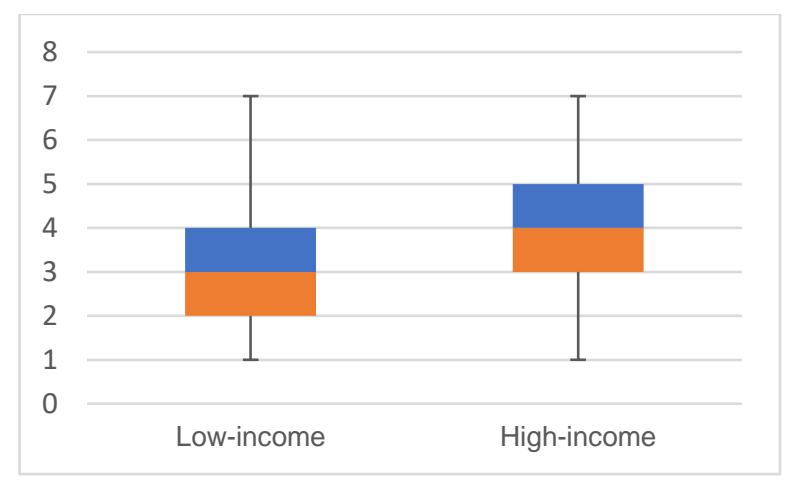

Fig. 3. Box plot for variable "confidence to assist with disaster management during an emergency"

\section{Conclusion}

Students are one of the most vulnerable and ignored groups of disaster-affected people. Hence, scholars and practitioners need to administer DRR education to help them gain the knowledge and preparation that are necessary to ensure their safety during a disaster. It is difficult to accomplish this task, as the current literature is barely sufficient to identify the impact of the students' demographic characteristics on their perception of disaster preparedness. This study addressed this issue by identifying the impacts of family income on students' perceptions of disaster preparedness and DRR education. A questionnaire was developed based on 22 variables, and 111 responses were collected. A statistical analysis revealed that family income has a significant impact on students' awareness of emergency procedures and communication systems offered by the university. It also impacts students' levels of confidence in assisting 
Proceedings of the Creative Construction e-Conference (2020) 060

Available online at e-2020.creative-construction-conference.com/proceedings/

their university during a disaster. This study will help educational institutions and practitioners in developing DRR resources that are best suited for students with certain demographic characteristics.

\section{References}

[1] S.J. Uddin, N. Pradhananga. "Construction workers' health and safety at Post-Disaster Reconstruction (PDR) Phase: A knowledge gap analysis". Florida Internationa University, 2019.

[2] H. Hu, T. Lei, J. Hu, S. Zhang, P. Kavan. "Disaster-mitigating and general innovative responses to climate disasters: Evidence from modern and historical China". International Journal of Disaster Risk Reduction, Vol. 28, pp. 664-673, 2018. https://doi.org/10.1016/j.ijdrr.3018.01.022

[3] T.M. Lee, E.M. Markowitz, P.D. Howe, C.Y. Ko, A.A. Leiserowitz. "Predictors of public climate change awareness and risk perception around the world". Nature Climate change, Vol. 5, pp 11, 2015. https://doi.org/10.1038/nclimate2728

[4] S. McKinnon, A. Gorman-Murray, D. Dominey-Howes. "Disasters, queer narratives, and the news: how are LGBTI disaster experiences reported by the mainstream and LGBTI media?". Journal of homosexuality, 64(1), 122-144, 2017. https://doi.org/10.1080/00918369.2016.1172901.

[5] Kermanshachi, S., \& Rouhanizadeh, B. "Feasibility analysis of post disaster reconstruction alternatives using automated BIM-based construction cost estimation tool". In Proceeding of CSCE 6th International Disaster Mitigation Specialty Conference, Montreal: Canadian Society of Civil Engineering, pp. 13-16. 2018.

[6] Safapour, E.; Kermanshachi, S. "Identification and categorization of factors affecting duration of post-disaster reconstruction of interdependent transportation systems". ASCE Construction Research Congress (CRC), 2019.

[7] Kermanshachi, S.; Bergstrand, K.; Rouhanizadeh, B. "Identifying, weighting and causality modeling of social and economic barriers to rapid infrastructure recovery from natural disasters: A study of hurricanes Harvey, Irma and Maria". Technical report, 2019.

[8] Rouhanizadeh, B.; Kermanshachi, S. "Comparative analysis of public's and decision-maker's perspectives on socioeconomic barriers causing delay in post-disaster recovery processes". ASCE Construction Research Congress (CRC), 2019.

[9] Rouhanizadeh, B., \& Kermanshachi, S. "Investigating the Relationships of Socioeconomic Factors Delaying Post-Disaster Reconstruction". In Proceedings of ASCE International Conference on Computing in Civil Engineering, pp. 17-19. 2019. https://doi.org/10.1061/9780784482445.005

[10] L. Onigbinde. "The impacts of natural disasters on educational attainment: Cross-country evidence from macro data." Master Thesis, The University of San Francisco, 2018

[11] Safapour, E., Kermanshachi, S., Nipa, T.J. A Damage-based Analysis of Rework in Reconstruction of Infrastructure Projects Due to Natural Disasters. Creative Construction Conference (CCC), 2020.

[12] Pamidimukkala A, Kermanshachi S, Kartick S. "Impact of Natural Disasters on Construction Projects: Strategies to Prevent Cost and Schedule Overruns in Reconstruction projects". Creative Construction Conference (CCC), 2020.

[13] Safapour E, Kermanshachi S, Nipa T J. "Analysis of Cost Performance Indicators in Reconstruction Projects: A Comparative Study of Low Vs. High Level Damages". Creative Construction Conference (CCC), 2020.

[14] Duffin. "Number of fatalities due to natural disasters in the United States in 2018, by type", 2020. Retrieved from https://www.statista.com/statistics/216831/fatalities-due-to-natural-disasters-in-the-united-states/, May 13, 2020.

[15] B. Pfefferbaum, J.A. Shaw. "Practice parameter on disaster preparedness". Journal of the American Academy of Child \& Adolescent Psychiatry, 52(11), 1224-1238, 2013. https:// doi.org/10.1016/j.jaac.2013.08.014

[16] Nipa T, J., Kermanshachi, S. Identification of the Resilience Dimensions and Determination of their Relationships in Critical Transportation Infrastructures. ASCE Construction Research Congress (CRC), 2019

[17] Rouhanizadeh, B.; Kermanshachi, S.; Dhamangaonkar, V. "Reconstruction of critical and interdependent infrastructures due to catastrophic natural disasters: lessons learned". ASCE Construction Research Congress, 2019.

[18] Safapour, E., Kermanshachi, S. „Investigation of the Challenges and Their Best Practices for Post-Disaster Reconstruction Safety: Educational Approach for Construction Hazards". Transportation Research Board 99th Annual Conference, 2019

[19] Pamidimukkala A, Kermanshachi S, Safapour E. Challenges in Post-Disaster Housing Reconstruction: Analysis of Urban Vs. Rural Communities". Creative Construction Conference (CCC), 2020

[20] Rouhanizadeh, B.; Kermanshachi, S.; Dhamangaonkar, V. "Identification and categorization of policy and legal barriers to long-term timely post-disaster reconstruction". Journal of Legal Affairs and Dispute Resolution in Engineering and Construction, Volume 11 issue 3, 2019. https://doi.org/10.1061/(asce)la.1943-4170.0000307

[21] Nipa T, J., Kermanshachi, S., Ramaji I, J. Comparative analysis of strengths and limitations of infrastructure resilience measurement methods. $7^{\text {th }}$ CSCE International Construction Speciality Conference (ICSC), 2019

[22] S. Kohn, J.L. Eaton, S. Feroz, A.A. Bainbridge, J. Hoolachan, D.J. Barnett. "Personal disaster preparedness: an integrative review of the literature." Disaster medicine and public health preparedness, 6(3), 217-231, 2012. https://doi.org/10.1001/dmp.2012.47

[23] Rouhanizadeh, B.; Kermanshachi, S.; Nipa, T. J. "Identification, categorization, and weighting of barriers to timely post-disaster recovery process". ASCE International Conference on Computing in Civil Engineering, 2019.

[24] Rouhanizadeh, B.; Kermanshachi, S. "A Systematic Approach to Analysis and Prioritization of the Socioeconomic Policies and Legal barriers to Rapid Post Disaster Reconstruction". 7th CSCE International Construction Specialty Conference (ICSC), 2019

[25] Federal Emergency Management Agency. Retrieved from https://www.ready.gov, May 13, 2020.

[26] Patel R, Kermanshachi S, Nipa T. " Establishment of a Framework to Measure Disaster Preparedness: Development of Strategies to Enhance Disaster Preparedness Activities. Creative Construction Conference (CCC), 2020.

[27] A. Tanner, B. Doberstein, "Emergency preparedness amongst university students". International journal of disaster risk reduction, 13, pp 409-413, 2015. https://doi.org/10.1016/j.ijdrr.2015.08.007

[28] Nipa T J, Kermanshachi S, Patel R, Tafazzoli M. "Disaster Preparedness Education: Construction Curriculum Requirements to Increase Students' Preparedness in Pre-and Post-Disaster Activities". Associated Schools of Construction (ASC) International Conference, 2020

[29] Patel R, Kermanshachi S, Mostafa N. "A Socioeconomic-based Analysis of Disaster Preparedness, Awareness, and Education". Creative Construction Conference, 2020

[30] M. Najafi, A. Ardalan, A. Akbarisari, A.A. Noorbala, H. Jabbari, "Demographic determinants of disaster preparedness behaviors amongst Tehran inhabitants, Iran." PLoS currents, 7, 2015. https://doi.org/10.1372/currents.dis.976b0ab9c9d9941cbbae3775a6c5fbe6

[31] Safapour E, Kermanshachi S." Assessing students higher education performance in minority and non-minority serving universities". IEEE Frontiers in Education (FIE), 2017. https://doi.org/10.1109/FIE.2017.8190452 
[32] Nipa T J, Kermanshachi S. " Assessment of open educational resources (OER) developed in interactive learning environments". Education and Information Technologies, 2019. https://doi.org/10.1007/s10639-019-10081-7

[33] Nipa T J, Kermanshachi S. " Analysis and assessment of graduate students' perception and academic performance using open educational resource (OER) course materials". ASEE Annual Conference \& Exposition, 2018.

[34] A. Jaradat, H. Mziu, J. Ibrahim. "Disaster preparedness in universities". Int J Comput Trends Tech, 19(1), pp 1-4, 2015.

[35] J.P. Mulilis, T.S. Duval, K. Bovalino. "Tornado preparedness of students, nonstudent renters, and nonstudent owners: lisues of PrE Theory 1". Journal of Applied Social Psychology, 30(6), pp 1310-1329, 2000. https://doi.org/10.1111/j.1559-1816.2000.tb02522.x

[36] Y. Tan, X. Liao, H. Su, C. Li, J. Xiang, Z. Dong. "Disaster preparedness among university students in Guangzhou, China: assessment of status and demand for disaster education." Disaster medicine and public health preparedness, 11(3), pp 310-317, 2017. https://doi.org/10.1017/dmp.2016.124

[37] L. Nahayo, L. Li, G. Habiyaremye, M. Richard, V. Mukanyandwi, E. Hakorimana, C. Mupenzi. "Extent of disaster courses delivery for the risk reduction in Rwanda." International journal of disaster risk reduction, 27, pp 127-132, 2018. https://doi.org/10.1016/j.ijdrr.2017.09.046

[38] A. Amri. "Challenges in implementing disaster risk reduction education: Views from the frontline in Indonesia." Macquarie University, Sydney, Australia, 2015.

[39] K. Haynes, T.M. Tanner. "Empowering young people and strengthening resilience: Youth-centred participatory video as a tool for climate change adaptation and disaster risk reduction". Children's Geographies, 13(3), pp 357-371, 2015. https://doi.org/10.1080/14733285.2013.848599

[40] J. Whittaker, K. Haynes, J. Handmer, J. McLennan. "Community safety during the 2009 Australian 'Black Saturday' bushfires: an analysis of household preparedness and response". International journal of wildland fire, 22(6), pp 841-849, 2013. https://doi.org/10.1071/WF12010

[41] H. Kim, M. Zakour. "Disaster preparedness among older adults: Social support, community participation, and demographic characteristics". Journal of Social Service Research, 43(4), pp 498-509, 2017. https://doi.org/10.1080/01488376.2017.1321081

[42] W.R. Donner, J. Lavariega-Montforti. "Ethnicity, income, and disaster preparedness in Deep South Texas, United States". Disasters, 42(4), pp 719-733, 2018. https://doi.org/10.1111/disa.12277

[43] D.H. Yao. "Factors that Influence Disaster Preparedness". Doctoral dissertation, California Baptist University, 2019.

[44] M. Käser, L. Maduz, T. Prior, F. Roth. "Individual Disaster Preparedness: Explaining disaster-related Information Seeking and Preparedness Behavior in Switzerland." pp. 1-34, ETH Zurich, 2019. https://doi.org/10.3929/ethz-b-000356695

[45] J.S. Gilhooly. "Analysis of Risk Factors in Emergency Preparedness in Tennessee". Doctoral dissertation, Capella University, 2018. 